Research Article

\title{
Genetic evaluation of the mating system in the blue-and-yellow macaw (Ara ararauna, Aves, Psittacidae) by DNA fingerprinting
}

\author{
Renato Caparroz ${ }^{1}$, Cristina Y. Miyaki ${ }^{2}$ and Allan J. Baker ${ }^{3}$ \\ ${ }^{1}$ Pós-graduação em Ecologia e Evolução, Instituto de Ciências Biológicas, \\ Universidade Federal de Goiás, Goiânia, GO, Brazil. \\ ${ }^{2}$ Departamento de Genética e Biologia Evolutiva, Instituto de Biociências, \\ Universidade de São Paulo, São Paulo, SP, Brazil. \\ ${ }^{3}$ Department of Natural History, Royal Ontario Museum, Toronto, Ontario, Canada.
}

\begin{abstract}
More than $90 \%$ of birds are socially monogamous, although genetic studies indicate that many are often not sexually monogamous. In the present study, DNA fingerprinting was used to estimate the genetic relationships between nestlings belonging to the same broods to evaluate the mating system in the socially monogamous macaw, Ara ararauna. We found that in 10 of 11 broods investigated, the nestlings showed genetic similarity levels congruent with values expected among full-sibs, suggesting that they shared the same parents. However, in one brood, the low genetic similarity observed between nestlings could be a result of intraspecific brood parasitism, intraspecific nest competition or extra-pair paternity. These results, along with available behavioral and life-history data, imply that the blue-and-yellow macaw is not only socially, but also genetically monogamous. However, the occurrence of eventual cases of extra-pair paternity cannot be excluded.
\end{abstract}

Key words: Ara ararauna, breeding behavior, DNA fingerprinting, monogamy, Psittacidae.

Received: June 17, 2010; Accepted: October 22, 2010.

\section{Introduction}

Even though more than $90 \%$ of birds are socially monogamous (Lack, 1968), genetic studies showed that extra-pair paternity (EPP) is found in approximately $90 \%$ of species studied (Griffith et al., 2002). Even among socially monogamous species, over $11 \%$ of the offspring are the result of EPP (Griffith et al., 2002). The occurrence of EPP is so widespread that recent research has tried to identify factors explaining its apparent absence in some species (Arnold and Owens, 2002; Griffith et al., 2002).

Although differences in life history and contemporary ecological factors have been proposed to account for interspecific variation in the level of EPP, there has been relatively little success in identifying robust biological correlates of this interspecific variation (Birkhead and Møller, 1996; Bennett and Owens, 2002). Phylogenetic analysis of EPP data has shown that more than $50 \%$ of interspecific variation can be explained by phylogeny (Arnold and Owens, 2002; Bennett and Owens, 2002; Griffith et al., 2002), thereby implying that differences in EPP rates are

Send correspondence to Renato Caparroz. Pós-graduação em Ecologia \& Evolução, Instituto de Ciências Biológicas, Universidade Federal de Goiás, Campus Samambaia, Caixa Postal 131, 74001-970, Goiânia, GO, Brazil. E-mail: renatocz @yahoo.com.br. likely to have been determined in the ancient evolutionary history of avian lineages (Griffith et al., 2002). However, the relative importance of phylogenetic constraints on EPP incidence remains largely unknown (Kingma et al., 2009).

The degree of paternal care appears to be a key predictor of genetic monogamy (Mulder et al., 1994; Birkhead and Møller, 1996; Gowaty, 1996). Females that can rear offspring with little or no paternal care are likely to seek extra-pair copulations, whereas, whenever paternal care is essential, EPP rates tend to be low (Griffith et al., 2002).

Another ecological factor that has been suggested to explain interspecific variation in the rate of EPP is the adult mortality rate (Mauck et al., 1999; Wink and Dyrcz, 1999). According to Mauck et al. (1999), abandonment of a reproductive event can be nonadaptive in species with short reproductive lifespans, even in the face of extreme uncertainty of paternity. This is possibly so because a new reproductive event may be very unlikely to occur. It seems that longevity explains $25 \%$ of the variation in EPP rates (Arnold and Owens, 2002; Griffith et al., 2002).

In some non-passeriform groups of birds that display male parental care and long reproductive lifespans, such as Sphenisciformes (e.g. Moreno et al., 2000), Procellariiformes (Quillfeldt et al., 2001), Strigiformes and Falconiformes (Muller et al., 2001), EPP seems to occur 
infrequently or may even be entirely absent. These studies indicated that the species studied are both socially and genetically monogamous.

Psittaciformes (parrots and cockatoos) comprise another group of long-lived birds with high levels of parental investment, wherein most species are considered to be socially monogamous (Forshaw, 1989; Sick, 1997). Data from genetic analysis of the few so far studied, indicate that all those with this characteristic appear to be genetically monogamous (Caparroz et al., 2001; Masello et al., 2002; Ekstrom et al., 2007; Taylor and Parkin, 2009). Thus, further analysis of other socially monogamous parrot species could contribute towards a better understanding, not only of the general genetic mating system in these non-passerine birds, but also the contribution of evolutionary and ecological factors determining EPP rates.

In the present work we used DNA fingerprinting to estimate the genetic relationship between nestlings in the same brood, in order to gather evidence of EPP in a socially monogamous species this being the blue-and-yellow macaw (Ara ararauna).

\section{Material and Methods}

Blood samples $(0.1 \mathrm{~mL})$ were collected from the brachial vein of 22 nestlings that had been found in 11 natural nests, thus two chicks per nest, at three localities in central Brazil (Table 1). Unfortunately, it was not possible to sample their putative parents, through the extreme difficulty and stress involved in capturing adults. The samples were stored at $-20{ }^{\circ} \mathrm{C}$ in $100 \%$ ethanol. Total genomic DNA was extracted from blood incubated overnight at $37{ }^{\circ} \mathrm{C}$ in a solution containing $0.1 \%$ SDS, $100 \mathrm{mM}$ Tris$\mathrm{HCl}$ (pH 8.0), $10 \mathrm{mM} \mathrm{NaCl}, 10 \mathrm{mM}$ EDTA and $10 \mathrm{mg} / \mathrm{mL}$ proteinase $\mathrm{K}$, and subsequently purified using the standard phenol-chloroform-isoamyl alcohol method (Bruford et al., 1992).

Table 1 - Sampling localities in Brazil and band sharing coefficients (x) based on multilocus minisatellite data between nestlings of blue-andyellow macaw of the same brood (two nestlings per brood).

\begin{tabular}{lcc}
\hline Locality (abbreviation) latitude/longitude & Nest & $\mathrm{x}$ \\
\hline Peixe, southeastern Tocantins (ST) & $\mathrm{P} 01$ & 0.59 \\
$12^{\circ} \mathrm{S}, 48^{\circ} \mathrm{W}$ & $\mathrm{P} 04$ & 0.73 \\
& $\mathrm{P} 06$ & 0.61 \\
\hline Cavalcante, northeastern Goiás (NG) & $\mathrm{C} 10$ & 0.48 \\
$13^{\circ} \mathrm{S}, 47^{\circ} \mathrm{W}$ & $\mathrm{C} 10 \mathrm{~B}$ & 0.68 \\
& $\mathrm{C} 13$ & 0.57 \\
& $\mathrm{C} 19$ & 0.61 \\
\hline Corginho, central Mato Grosso do Sul (CMS) & $\mathrm{A} 06$ & 0.87 \\
$19^{\circ} \mathrm{S}, 54^{\circ} \mathrm{W}$ & $\mathrm{A} 08$ & 0.22 \\
& $\mathrm{~A} 11$ & 0.61 \\
\hline
\end{tabular}

Approximately $6 \mu \mathrm{g}$ of genomic DNA from each nestling were digested overnight with the restriction enzyme HaeIII at $37{ }^{\circ} \mathrm{C}$. DNA fragments were electrophoresed and then transferred onto nylon membranes by Southern blotting (Sambrook et al., 1989). Each membrane was hybridized with the human multilocus minisatellite probe 33.6 (Jeffreys et al., 1985a), and then washed in $0.25 \mathrm{M} \mathrm{Na}_{2} \mathrm{HPO}_{4}, 1 \% \mathrm{SDS}, 2 \mathrm{x}$ SSC, $0.1 \% \mathrm{SDS}$, and $1 \mathrm{x}$ $\mathrm{SSC}, 0.1 \%$ SDS at $65{ }^{\circ} \mathrm{C}$. The filters were autoradiographed at $-70{ }^{\circ} \mathrm{C}$, using Kodak RX film with two intensifying screens. Only bands between 4.0 and $23.0 \mathrm{~kb}$ were analyzed, as described by Westneat (1990). Bands sharing coefficient between individuals (index of similarity) were estimated using the formula: $x=2 \mathrm{~N}_{\mathrm{AB}} /\left(\mathrm{N}_{\mathrm{A}}+\mathrm{N}_{\mathrm{B}}\right)$, where $\mathrm{N}_{\mathrm{AB}}$ is the number of bands shared between individuals $\mathrm{A}$ and $\mathrm{B}$, and $\mathrm{N}_{\mathrm{A}}$ and $\mathrm{N}_{\mathrm{B}}$ the number of bands present in these same two individuals, respectively (Wetton et al., 1987; Bruford et al., 1992). Only bands with the same electrophoretic mobility (migration distance of band centers within $0.5 \mathrm{~mm}$ ) between two individuals were considered to be one and the same allele. The frequency $(q)$ of each scorable band was estimated as: $q=1-(1-x)^{1 / 2}$ (Jeffreys et al., 1985b). Assuming the absence of mutations and linkage, the mean expected similarity index between full-sibs was estimated by: $x_{\mathrm{i}}=\left(4+5 q-6 q^{2}+q^{3}\right) /[4(2-q)]$ (Jeffreys et al., 1985c). The mean expected similarity index between half-sibs was considered as half of $x_{\mathrm{i}}$, i.e. $x_{\mathrm{h}}=x_{\mathrm{i}} / 2$. The statistical significance of the difference in similarity indexes between nestlings of the same brood versus other broods was calculated by using the Mann-Whitney U test as implemented in Statistica 7.1 (StatSoft).

\section{Results}

The restriction enzyme/minisatellite probe combination used here produced band patterns that were exclusive to each individual (data not shown). The mean number of bands scored per individual in the three localities ranged from $19.40 \pm 5.18$ to $23.83 \pm 2.79$ (Table 2). Band sharing coefficients between nestlings of the same brood varied from 0.48 to 0.88 (Table 1 ). These coefficients were similar to those expected for full-sibs, and statistically higher than those observed among nestlings from different broods (considered non-related, $\mathrm{p}<0.01$; Mann-Whitney U test; Table 2). The only exception was a nestling-pair found in nest A08 with a coefficient of 0.22 . This value was similar to those observed among nestlings from different broods (considered non-related), and to those expected among half-sibs (Table 2).

\section{Discussion}

We found that in 10 of the 11 broods of Ara ararauna investigated, nestlings showed genetic similarity levels congruent with those expected between full-sibs, thereby implying that the majority of nestlings of the same brood 
Table 2 - Number of nests of Ara ararauna (Nnests) analyzed per locality, mean number of bands scored (n), mean band sharing coefficients estimated between nestlings of the same brood (xs) and between nestlings of different brood (xd), the frequency of each scorable band (q) and expected coefficient between full sibs (xi) and half-sibs (xh).

\begin{tabular}{lccccccc}
\hline Locality & Nnests & $\mathrm{n} \pm \mathrm{sd}$ & $\mathrm{xs} \pm \mathrm{sd}$ & $\mathrm{xd} \pm \mathrm{sd}$ & $\mathrm{q}$ & $\mathrm{xi}$ & $\mathrm{xh}$ \\
\hline ST & 03 & $19.40 \pm 5.18$ & $0.642 \pm 0.074$ & $0.227 \pm 0.106$ & 0.121 & 0.601 & 0.300 \\
NG & 04 & $22.91 \pm 3.91$ & $0.585 \pm 0.085$ & $0.206 \pm 0.092$ & 0.109 & 0.591 & 0.296 \\
CMS & 04 & $23.83 \pm 2.79$ & $0.580 \pm 0.268$ & $0.229 \pm 0.099$ & 0.122 & 0.602 & 0.301 \\
\hline
\end{tabular}

sd - standard deviation. Refer to Table 1 for locality abbreviations.

were produced by the same parents. As the actual social parents could not be sampled, it is not possible to rule out the possibility that both exceptional nestlings were the result of either intraspecific brood parasitism or intraspecific nest competition, or even full-brood EPP (with only one mother and one father involved). To further investigate this, it would be necessary to develop a methodology for sampling social parents without causing undue stress.

In contrast, the low genetic similarity observed between nestlings of one brood (nest A08, Table 1) suggests that they were not full-sibs. In this case, both social parents were probably not genetic parents of at least one of the chicks, possibly the result of either intraspecific brood parasitism or intraspecific nest competition, or even, as mentioned, EPP. As discussed previously, it would be necessary to obtain samples from the social parents to test these alternatives. Based on these results, at least $9 \%$ of the broods could not be attributed to both social parents. On considering three other previously analyzed broods (Caparroz et al., 2001), this rate decreases to $7 \%$. To date, there are only two reported cases of the presence of nonfull sibs in the same brood, in socially monogamous parrot species, one in the green-winged macaw (Ara chloropterus, Caparroz et al., 2001), and the other in the burrowing parrot (Cyanoliseus patagonus, Masello et al., 2002). In both cases, the authors suggested that intraspecific brood parasitism (or intraspecific nest competition) was the most likely explanation.

The blue-and-yellow macaw is a long-lived socially monogamous species, with male parental care. These biological traits are assumed to be correlated with low EPP rates (see Introduction). Once successfully fledged from the nest, macaws seem to have a high survival rate (Myers and Vaughan, 2004). Well-documented longevity records for macaws include a specimen of $A$. ararauna which was housed at the Copenhagen Zoo for 46 years (Brouwer et al., 2000). Therefore, the offspring of a single breeding season most likely represents a small proportion of the potential lifetime reproductive production. Any reduction in adult survival of long-lived species by the investment in raising current offspring, exerts a larger influence on lifetime reproductive success than in short-lived bird species (Masello et al., 2002). Thus, long-lived birds, such as macaws, are not expected to invest in broods of doubtful paternity (Mauck et al., 1999). However, the parents in both hyacinth
(Anodorhynchus hyacinthinus, N.M.R. Guedes, personal communication) and scarlet (Ara macao, D.J. Brightsmith, personal communication) macaws accept nestlings translocated from other broods, i.e. the social parents are unable to identify chicks from other pairs. In fact, this behavior, as observed in these two macaws, suggests selective inability in recognizing EPP offspring, thereby implying that EPP could be rare or nonexistent in these species. As A. macao and $A$. ararauna are phylogenetically related, it would be expected that $A$. ararauna parents are also unable to distinguish their own biological chicks from unrelated ones that are eventually in their nest.

The low rate of EPP observed in A. ararauna may be due to effective male investment in avoiding EPP, as they are strongly committed to parental care. Two main paternity-guarding strategies have been proposed for birds, namely, mate-guarding and frequent within-pair copulation (Birkhead and Møller, 1992). Blue-and-yellow macaws have nearly always been observed flying in pairs or in family groups (Gilardi and Munn, 1998; R. Caparroz, personal observation), except when females are incubating or brooding. Furthermore, males are always observed hanging in close proximity to the nest during the egg-laying period, and seem to follow the female every time she leaves the nest (R. Caparroz, personal observation). This behavior is possibly related to mate-guarding by males.

Other contemporary ecological factors, such as breeding density and breeding synchrony have also been proposed as correlated with EPP rates (see Griffith et al., 2002). However, there is insufficient information on breeding density and synchrony in the blue-and-yellow macaw to permit further analysis. Further investigation of the influence of these factors is required when the relevant data are available. Moreover, since there is possibly a large phylogenetic component in EPP frequency (see Introduction), evolutionary inertia may contribute to the low levels or absence of EPP in this macaw species.

Overall, our genetic results, along with available information on behavior and life history, testify to the blueand-yellow macaw being socially and genetically monogamous. Nevertheless, the occurrence of full-brood EPP in some of the nests analyzed cannot be excluded. In at least $7 \%$ of the broods studied here, one of the nestlings could be a result of nest parasitism or EPP. Access to parent-samples 
is essential to confirm our findings, as well as to accurately estimate EPP rates in this species.

\section{Acknowledgments}

We wish to thank A. Wajntal, S. Matiolli, D. Meyer and D. J. Brightsmith for discussions about specific topics, as well as M. S. Santos, E. S. Tavares, C. C. Ribas and C. Bertolloto for providing field assistance. We are also grateful to the Director and employees of the National Park of Chapada dos Veadeiros for assistance during field work. This work was supported by the Fundação de Amparo a Pesquisa do Estado de São Paulo (FAPESP), Coordenação de Aperfeiçoamento de Pessoal de Nível Superior (CAPES), and Conselho Nacional de Desenvolvimento Cientifico e Tecnológico (CNPq).

\section{References}

Arnold KE and Owens IPF (2002) Extra-pair paternity and egg dumping in birds: Life history, parental care and the risk of retaliation. Proc R Soc Lond B 269:1263-1269.

Bennett PM and Owens IPF (2002) Evolutionary Ecology of Birds: Life History, Mating Systems and Extinction. Oxford University Press, Oxford, 296 pp.

Birkhead TR and Møller AP (1996) Monogamy and sperm competition in birds. In: Black JM (ed) Partnerships in Birds. Oxford University Press, Oxford, pp 323-343.

Birkhead TR and Møller AP (1992) Sperm Competition in Birds: Evolutionary Causes and Consequences. Academic Press, San Diego, 272 pp.

Brouwer K, Jones ML, King CE and Schifter H (2000) Longevity records for Psittaciformes in captivity. Int Zoo Yearb 37:299-316.

Bruford MW, Hanotte O, Brookfield JFY and Burke T (1992) Single locus and multilocus DNA fingerprinting. In: Hoelzel AR (ed) Molecular Genetic Analysis of Populations. A Practical Approach. Oxford University Press, New York, pp 225-269.

Caparroz R, Guedes NMR, Bianchi CA and Wajntal A (2001) Analysis of the genetic variability and breeding behavior of wild populations of two macaw species (Psittaciformes, Aves) by DNA fingerprinting. Brazil J Ornithol - Ararajuba 9:43-49.

Ekstrom JMM, Burke T, Randrianaina L and Birkhead TR (2007) Unusual sex roles in a highly promiscuous parrot: The Greater Vasa Parrot Caracopsis vasa. Ibis 149:313-320.

Forshaw JM (1989) The Parrots of the World. 3rd edition. Lansdowne Press, Willoughby, 584 pp.

Gilardi JD and Munn CA (1998) Patterns of activity, flocking, and habitat use in parrots of the Peruvian Amazon. Condor 100:641-653

Griffith SC, Owens IPF and Thuman KA (2002) Extra pair paternity in birds: A review of interspecific variation and adaptive function. Mol Ecol 11:2195-2212.
Gowaty PA (1996) Battle of the sexes and origins of monogamy. In: Black JM (ed) Partnerships in Birds: The Study of Monogamy. Oxford University Press, Oxford, pp 21-52.

Jeffreys AJ, Wilson V and Thein SL (1985a) Hypervariable minisatellite regions in human DNA. Nature 314:67-73.

Jeffreys AJ, Wilson V and Thein SL (1985b) Individual specific "fingerprints" of human DNA. Nature 316:76-79.

Jeffreys AJ, Brookfield JFY and Semeonoff R (1985c) Positive identification of an immigration test-case using human DNA fingerprints. Nature 317:818-819.

Kingma SA, Hall ML, Segelbacher G and Peters A (2009) Radical loss of an extreme extra-pair mating system. BMC Ecol 9:15.

Lack D (1968) Ecological adaptations for breeding in birds. Methuen Ltd, London, 409 pp.

Masello JF, Sramkova A, Quillfeldt P, Epplen JT and Lubjuhn T (2002) Genetic monogamy in burrowing parrots Cyanoliseus patagonus? J Avian Biol 33:99-103.

Mauck RA, Marshall EA and Parker PG (1999) Adult survival and imperfect assessment of parentage: Effects on male parenting decisions. Am Nat 154:99-109.

Moreno J, Boto L, Fargallo JA, de Leon A and Potti J (2000) Absence of extra-pair fertilizations in the chinstrap penguin Pygosceles antartica. J Avian Biol 31:580-583.

Muller W, Epplen JT and Lubjuhn T (2001) Genetic paternity analyses in little owls (Athene noctua): Does the high rate of parental care select against extra-pair young? J Ornith 142:195-203.

Mulder RA, Dunn PO, Cockburn RA, Lazenby-Cohen KA and Howell MJ (1994) Helpers liberate female fairy-wrens from constraints on extra-pair mate choice. Proc R Soc Lond B 255:223-229.

Myers M and Vaughan C (2004) Movement and behaviour of scarlet macaws (Ara macao) during the post-fledgling dependence period: Implications for in situ versus ex situ management. Biol Conserv 118:411-420.

Quillfeldt P, Schmoll T, Epplen JT and Lubjuhn T (2001) Genetic monogamy in Wilson's storm-petrel. Auk 118:245-251.

Sambrook J, Fritsch EF and Maniatis T (1989) Molecular Cloning. A Laboratory Manual. 2nd edition. Cold Spring Harbor Laboratory Press, New York, 1659 pp.

Sick H (1997) Ornitologia Brasileira, Uma Introdução. Nova Fronteira, Rio de Janeiro, 912 pp.

Taylor TD and Parkin DT (2009) Preliminary evidence suggests extra-pair mating in the critically endangered Echo Parakeet Psittacula eques. Afr Zool 44:71-74.

Westneat DF (1990) Genetic parentage in the indigo butting: A study using DNA fingerprinting. Behav Ecol Sociobiol $35: 877-886$

Wetton JH, Carter RE, Parkin DT and Walters D (1987) Demographic study of a wild house sparrow population by DNA fingerprinting. Nature 327:147-149.

Wink M and Dyrcz A (1999) Mating systems in birds: A review of molecular studies. Acta Ornith 34:91-109.

\section{Associate Editor: Louis Bernard Klaczko}

License information: This is an open-access article distributed under the terms of the Creative Commons Attribution License, which permits unrestricted use, distribution, and reproduction in any medium, provided the original work is properly cited. 